\title{
Ferramentas tecnológicas para o desenvolvimento da atenção e da percepção da progressão temática no texto
}

\author{
Technological tools for developing attention and thematic progression perception in text
}

Gabriela Fontana Abs da Cruz ${ }^{1}$, Gabrielle Perotto de Souza da Rosa ${ }^{2}$ Patricia de Andrade Neves $^{3}$, Patrícia Martins Valente ${ }^{4}$

1 Doutoranda em Linguística pela PUCRS (bolsista CAPES). Professora do IFRS . Campus Restinga.

E-mail: gabriela.abs@gmail.com

Doutoranda em Linguística pela PUCRS (bolsista CAPES). Professora de Língua Portuguesa nas Redes Estadual e Municipal de Ensino.

E-mail: gabiperotto@gmail.com

Mestranda em Linguística pela PUCRS (bolsista CNPq)

E-mail: andradeneves.patricia@gmail.com

Doutoranda em Linguistica pela PUCRS (bolsista CAPES). Professora de Língua E-mail: paty valente13@hotmail.com
RESUMO: A leitura e a compreensão textual, assim como a progressão temática e a atenção estão intimamente ligadas quando se trata de aprendizagem. A falta de foco atencional durante a realização da leitura gera dificuldades na compreensão do texto, que, consequentemente, comprometem o amadurecimento do aluno enquanto leitor, bem como seu desempenho escolar. 0 objetivo deste trabalho é avaliar a funcionalidade de três ferramentas tecnológicas, a saber, Hot Potatoes, Ardora e JClic, construindo atividades virtuais que auxiliem no desenvolvimento da atenção, durante a leitura, e da percepção da progressão temática do texto lido. Após a criação das atividades, observou-se que os três programas apresentam recursos que podem contribuir com o trabalho do professor. Porém, o software que foi mais acessível para a elaboração das tarefas foi o Ardora, além de ter uma apresentação visual mais favorável para atrair a atenção involuntária do estudante e motivá-lo a realizar o que é solicitado.

PALAVRAS-CHAVE: Leitura; Atenção; Progressão temática; Tecnologia.

ABSTRACT: Reading and text comprehension, as well as thematic progression and attention are closely related when it talks about learning. The lack of attentional focus during reading causes difficulties in text comprehension, that, consequently, impairs the maturity of the student as a reader and in its school performance. The purpose of this study is to evaluate the functionality of three softwares, namely, Hot Potatoes, JClick and Ardora elaborating virtual activities that can help in attention development, during reading, and in text thematic progression. After the creation of these school activities, it was noted that these three softwares have resources to contribute with the teacher methodology. However, Ardora was the most accessible software in the activities elaboration, besides it has more favorable visual presentation to attract the student involuntary attention and motivate him to execute what is requested.

KEYWORDS: Reading; Attention; Thematic progression; Technology. 


\section{Introdução}

atenção é um processo cognitivo crucial para o aprendizado, pois se refere à capacidade de focalizar informações selecionadas por tempo suficiente (a partir da inibição de elementos que não são pertinentes à tarefa em execução e que possam vir a interferir no processo), a fim de que haja o desenvolvimento adequado de habilidades cognitivas (COMMODARI; GUARNERA, 2005). A falta de atenção é um dos aspectos geralmente apontados pelos profissionais da educação como prejudiciais para a qualidade de ensino, pois dificulta o aprofundamento de conhecimentos essenciais das disciplinas (SOUZA; GUARESI, 2012, p. 31).

$\mathrm{Na}$ leitura, isso não é diferente. A falta de foco atencional durante a realização dessa tarefa gera dificuldades na compreensão do texto, que, consequentemente, comprometem o amadurecimento do aluno enquanto leitor, bem como seu desempenho escolar (FONSECA, 2013, p. 13). Um dos aspectos textuais relevantes para que haja a compreensão leitora é a coerência, visto que ela é a responsável pelo sentido do texto. Sendo a coerência uma propriedade ideativa do texto (SIMON, 2008, p. 2), um dos princípios que a garantem, e que será tema deste artigo, é a progressão temática. Esse aspecto refere-se ao equilíbrio entre informações novas e dadas no texto, que é estabelecido conjuntamente com as relações coesivas entre os elementos que o constituem.

A partir de nossas experiências como professoras de Ensino Fundamental, que vão ao encontro dos aspectos anteriormente citados, vemos a necessidade de buscar recursos que auxiliem no desenvolvimento da compreensão leitora de nossos alunos. Por esse motivo, o presente trabalho objetiva avaliar a funcionalidade de três ferramentas tecnológicas, a saber, Hot Potatoes, Ardora e JClic, em relação à possibilidade de construir atividades virtuais que auxiliem no desenvolvimento da atenção, durante a leitura, e da percepção da progressão temática do texto lido. Para tanto, este artigo está organizado em cinco seções. A primeira delas apresentará os aspectos referentes à compreensão leitora; a segunda, o referencial teórico sobre a progressão temática; a terceira tratará da atenção; a quarta será destinada à metodologia do trabalho, em que serão apresentadas a análise do texto escolhido, a descrição das atividades propostas e uma breve descrição dos recursos tecnológicos utilizados para a construção desses materiais. Por fim, serão apresentados os resultados e as considerações finais deste trabalho.

\section{Leitura e compreensão}

A leitura é um ato social entre leitor e autor que interagem obedecendo a objetivos e necessidades socialmente estabelecidos (KLEIMAN, 1992); "uma tarefa complexa que depende de processos perceptivos, cognitivos e linguísticos" (COLOMER; CAMPS, 2002, p. 32). Para tanto, o leitor precisa ter competência sintática, semântica e textual, além de uma competência específica da realidade histórico-social refletida pelo texto.

O sentido é construído durante a leitura através de transações entre o leitor e o texto que está sendo lido, e depende da atuação do cérebro, da realidade representada, de compartilhamento de esquemas/conhecimentos entre escritor e leitor, de sintaxe, de léxico, de conceitos e de contexto social (GOODMAN, 1991). O ato de ler é "um jogo psicolinguístico de predição", que envolve a interação entre pensamento e linguagem (GOODMAN, 1976, p. 70). A predição pode se realizar em todos os níveis de constituição da língua: fonológico, morfológico, sintático, semântico e pragmático (PEREIRA, 2002). A busca de significado é a característica mais importante do processo de leitura, pois este é construído e reconstruído enquanto se lê, uma vez que se acomoda nova informação e se adapta o significado em formação, obtendo 
novas percepções. Por isso, a leitura é compreendida como um processo dinâmico ativo, durante o qual o leitor faz uso de todos os seus esquemas conceptuais na busca da compreensão (GOODMAN, 1976).

A leitura das palavras se dá não letra por letra nem sílaba por sílaba, mas como um todo. $O$ leitor proficiente processa por blocos - que são as unidades de informação. Desse modo, há uma combinação de informação visual (aquela que vem da página escrita e contribui com $25 \%$ da informação necessária à compreensão) e não visual (que consiste no conhecimento e na experiência prévios do leitor), uma interação entre leitor e texto (SMITH, 2003).

A compreensão, por sua vez, é a possibilidade de relacionar aquilo que observamos ao conhecimento, intenções e expectativas que já possuímos em nossas mentes (SMITH, 2003), ou seja, "envolve processos cognitivos múltiplos" (KLEIMAN, 1992, p. 9). Para tanto, o leitor utiliza-se de estratégias, as quais podem ser classificadas como cognitivas (operações inconscientes, ações realizadas pelo leitor sem estar ciente disso, para atingir algum objetivo de leitura) e metacognitivas (operações controladas conscientemente, realizadas com algum objetivo em mente). Como exemplo de estratégia cognitiva, pode-se citar o processo inferencial de leitura; e de metacognitiva, a predição. O processo inferencial, segundo Ferreira e Dias (2004, p. 441), possibilita ao leitor a atribuição de coerência ao texto, conferindo-lhe sua interpretação. Permite que os sentidos construídos pelo leitor na interação com o texto sejam organizados e torna possível o estabelecimento de associações entre as partes deste, entre elas e o contexto. Em relação à predição, prever é fazer perguntas e compreender é responder a elas.

Em se tratando de compreensão textual, é importante saber que texto é uma unidade semântica em que vários elementos de significação são materializados através de categorias lexicais, sintáticas, semânticas e estruturais (KLEIMAN, 1992). Ou ainda, uma ocorrência comunicativa que preenche sete critérios de textualidade: coerência e coesão (centrados no texto), intencionalidade, aceitabilidade, situacionalidade, informatividade e intertextualidade (centrados no usuário) (BEAUGRANDE; DRESSLER, 1983), dentre os quais serão apresentados - neste artigo - somente os dois primeiros.

A coesão e a coerência são conceitos intimamente relacionados e responsáveis pela textualidade, isto é, o que faz com que um texto seja reconhecido como tal, em um nível conceitual e linguístico. Essa característica é alcançada somente quando determinadas exigências são satisfeitas e a coesão e a coerência são estabelecidas adequadamente.

A coesão está relacionada à microestrutura. Seu conceito é semântico e diz respeito às relações de sentido que existem no interior do texto e que se organizam superficial e linearmente. É reconhecível através de recursos semânticos, tais como marcas linguísticas, índices formais e conetivos (conjunções) (HALLIDAY; HASAN, 1976). Os mecanismos coesivos são divididos em cinco categorias, de acordo com o modo com que os itens lexicais e gramaticais relacionam-se com o texto e no texto: referência, substituição, elipse, conjunção e coesão lexical (HALLIDAY; HASAN, 1976).

A coerência, por outro lado, não é marcada explicitamente, mas é subjacente à superfície textual. Ela é responsável pela hierarquização dos elementos linguísticos, pela unidade e pela continuidade de sentido ao longo do texto. A coerência é, portanto, global e está relacionada à macroestrutura textual.

\section{Progressão temática}

Um dos aspectos que torna o texto coerente é, de acordo com Charolles (1978, p. 20), a metarregra de progressão, também conhecida como progressão temática. Essa metarregra permite que o texto seja fluido ao restringir a repetição excessiva do mesmo tópico e ao prever um equilíbrio 
entre o tema e a informação nova para que não haja uma quebra na continuidade temática.

Os linguistas da Escola Funcionalista de Praga ${ }^{1}$ propuseram os conceitos de tema e rema para que se compreendesse melhor o que seria a progressão temática. 0 tema, segundo eles, é o ponto de partida, a informação já contida no texto, o enunciado central; já o rema é a informação nova, a expansão, o avanço textual de forma coerente.

Daněs (1974) classifica a progressão temática de cinco formas: progressão linear, progressão do tema constante, progressão de temas derivados, progressão por subdivisão do rema e progressão com salto temático, as quais estão esquematizadas na Figura 1.

Na progressão linear (esquema 1), o rema de cada enunciado, ou até mesmo parte dele, é convertido em um novo tema para o enunciado seguinte. Na progressão de tema constante (esquema 2), surgem, a partir de um mesmo tema, diferentes remas. Um exemplo disso é a parlenda "Uma pulga na balança/ Deu um pulo/E foi à França", em que o tema de todos os enunciados, mesmo que elíptico, é "pulga". Na progressão de temas derivados (esquema 3), há um tema geral ("hipertema") e dele são gerados subtemas. Desse modo, os subtemas derivados de T (T1, T2, T3, etc.) introduzem informações novas. Na progressão por divisão de rema (esquema 4), a informação nova é segmentada e, a partir desses elementos, surgem novos temas. Por fim, na progressão com salto temático (esquema 5), ocorre a omissão de um segmento da sequência de uma progressão temática linear. Esse segmento, no entanto, pode ser deduzido a partir do contexto.

${ }^{1}$ A Escola de Praga, de 1926, era formada pelos linguistas russos Serguei Karcevski, Nikolai Trubetskoi e Roman Jakobson, entre outros, sendo os dois últimos os principais líderes da corrente. 0 funcionalism 作 nasceútica da fonologi Os funguir também o fon co cón traços pertinentes, distintivos ou funcionais dos fonemas.
Figura 1 - Tipos de progressão temática. Esquemas 1 a 4 propostos por Daněs $(1974)^{2}$ e 5, com base nesse autor, mas elaborado por Moreira (1991)

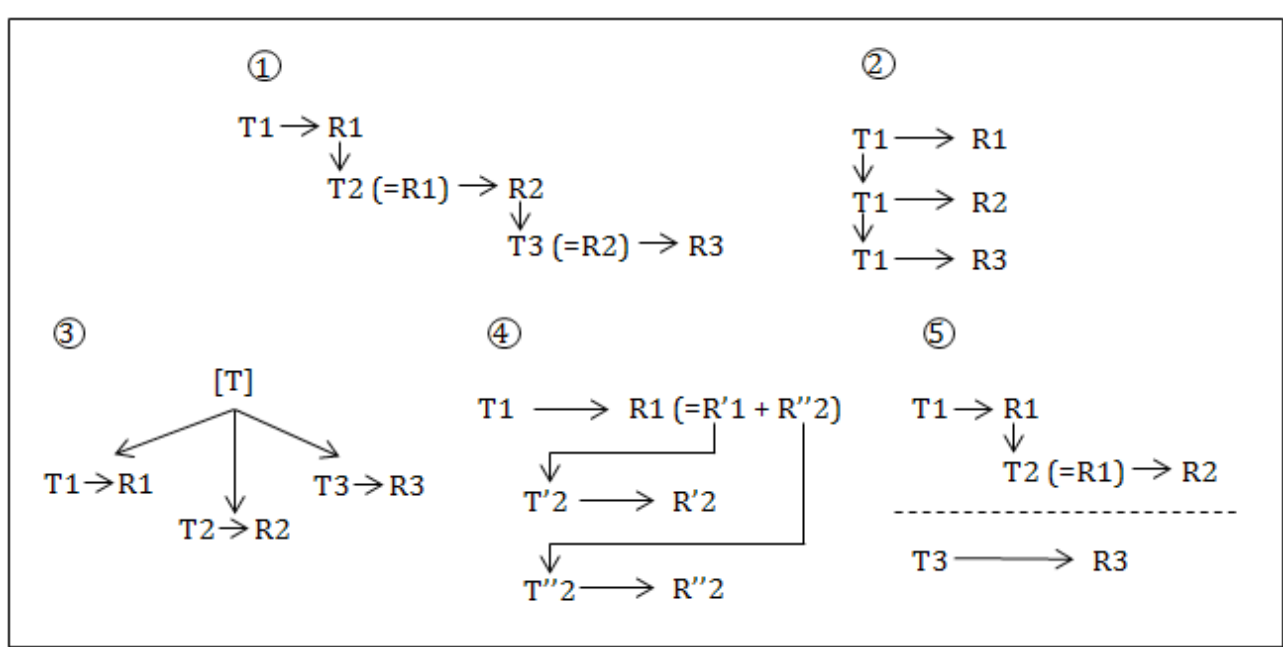

Koch (2004, p. 93) afirma que a progressão temática varia conforme o tipo textual: em textos descritivos, por exemplo, a progressão do tema constante é a que melhor se adapta; em textos expositivos ou argumentativos, o mais adequado é a progressão por subdivisão do rema; já a progressão do tema constante e a com salto temático são adequadas a todos os tipos de textos. No entanto, um mesmo texto pode ser composto por uma combinação desses diferentes tipos de progressão temática, principalmente se forem textos extensos (COMBETTES, 1983. p. 91).

Em textos narrativos, como a fábula (utilizado na sugestão de atividades para o presente artigo), a progressão temática é caracterizada pela ordenação temporal e pela composição da sequência narrativa. De acordo com

2 Daněs propõe que o tema seja representado por "T" e que o rema seja representado por "R". À medida que o texto avança, as alterações do tema e do rema são representadas por uma sequência numérica que acompanha "T" (T1, T2, T3...) e "R" (R1, R2, R3...) 
Adam (2011, p. 205), essa sequência deve ser constituída por uma estrutura hierárquica com sete proposições narrativas (Pn), sendo cinco delas de base e duas opcionais. As de base são: (Pn1) situação inicial (antecede o processo), (Pn2) nó (parte inicial do processo), (Pn3) reação ou avaliação (o percurso do processo), (Pn4) desenlace (final do processo) e (Pn5) situação final (após o processo). As proposições opcionais são $\operatorname{Pn} 0$ e $\operatorname{Pn} \Omega$ e correspondem, respectivamente, a uma abertura do texto (como um resumo ou um prefácio) e a um encerramento (em que pode haver uma avaliação final do fato narrado, como ocorre com a "moral da história" das fábulas). A partir do momento em que há a utilização adequada dos elementos da progressão temática, a produção e o sentido do texto são construídos, os parágrafos tornam-se articulados com as informações novas desenvolvidas e em concordância com as anteriores. Dessa forma, a estrutura hierárquica de proposições narrativas auxilia na construção de um texto narrativo coerente.

\section{Atenção}

O ser humano recebe uma quantidade expressiva de estímulos a todo tempo e, portanto, precisa selecionar os mais importantes e ignorar os demais. Para Luria (1979, p. 1), "a seleção dessa informação necessária, o asseguramento dos programas seletivos de ação e a manutenção de um controle permanente sobre elas são convencionalmente chamados de atenção".

A função da atenção é selecionar a atividade consciente, manifestandose igualmente na percepção, nos processos motores e no pensamento. Se não houvesse a seleção, não teríamos como organizar todo o pensamento e a informação, nem solucionar problemas.

Os fatores que determinam a atenção podem ser divididos em dois grupos: o primeiro é composto pela estrutura dos estímulos externos que chegam até o indivíduo e o segundo pelas atividades do próprio sujeito. O primeiro grupo é caracterizado por dominar o sentido, o objeto e a estabilidade da atenção, que estão próximos da estrutura da percepção. Sua característica mais relevante é a intensidade do estímulo, visto que a atenção do sujeito é sempre atraída por aquele que possui mais força. Se houver dois estímulos de intensidades semelhantes atuando em um mesmo campo, a atenção oscila e torna-se instável. Outra característica importante é a novidade, que, geralmente, atrai a atenção para si e provoca um reflexo orientado ${ }^{3}$ especial.

A percepção dos estímulos exteriores depende de sua organização estrutural. 0 indivíduo não consegue perceber diversos estímulos se esses estiverem desordenados e dispersos. Portanto, a organização em estruturas é um dos meios mais poderosos de direção da percepção humana e um dos fatores mais importantes de sua ampliação. Luria (ibidem, p. 4) afirma que "todos os referidos fatores, que determinam o sentido e o volume da atenção, situam-se entre as peculiaridades dos estímulos externos que atuam sobre o homem". É importante saber disso para aprender a dirigir a atenção para o que se pretende alcançar.

No segundo grupo, encontra-se mais latente a influência pelas necessidades, pelos interesses e pelos objetivos do sujeito sobre o processo de sua atividade. Dessa forma, a atenção não é motivada por instintos biológicos, mas por fatores motivacionais complexos que se formam na história social do indivíduo. Também a atenção em atividades novas sempre é mais concentrada do que em atividades automatizadas, o que mostra que o sentido da atenção é determinado pela estrutura psicológica da tarefa e depende do grau de automatização. O processo de automatização faz com que certas ações que chamavam atenção do sujeito comecem a deslocar-se

${ }_{3}$ Reflexo orientado - provocado pelo surgimento de um estímulo novo ou essencial para o sujeito. 
para os objetivos finais, deixando de ser atraída por operações rotineiras. A atividade não concluída e o problema não resolvido, no entanto, costumam atrair a atenção do sujeito e provocam nele tensão, motivando-lhe a trabalhar constantemente com a atenção ativada. Luria (ibidem, p. 6) diz que "a atenção do homem é determinada pela estrutura de sua atividade, reflete o seu processo e lhe serve de mecanismo de controle", o que torna a atenção humana um dos aspectos mais importantes da sua atividade consciente.

O caráter seletivo dos processos psíquicos da atenção é assegurado pelo estado de vigília do córtex, onde há um nível alto de excitabilidade. Os dados da região cortical e os neurônios não específicos que ali se encontram respondem a cada mudança de situação e são um importante aparelho que modifica o estado de atividade do cérebro e regula a sua prontidão para a ação. Os neurônios da novidade também são chamados de células da atenção por alguns autores (LURIA, 1979).

O reflexo orientado é compreendido por Luria (1979) como a base da atenção, e o tipo que merece maior ênfase neste trabalho é a reação ativa às mudanças de situações, pode ser provocado por um estímulo condicionado, como uma palavra, desencadeando, no sujeito, ocorrências de alerta, preocupação, expectativa, etc. A alta seletividade do reflexo orientado pode manifestar-se em relação a sua parte afetiva e motora. O ser humano, estando em ambiente escuro, sabe que, ao ligar a luz, deve se preparar para receber o impacto da claridade em seus olhos. Ou seja, a reação ativadora do reflexo orientado tem caráter seletivo. Luria (ibidem, p. 20) explica que

as ocorrências de reflexo orientado da ativação podem ser geradas por qualquer mudança de situação ou pela expectativa de um estímulo novo ou essencial. Elas se extinguem paulatinamente como resultado da habituação e tornam a manifestar-se com a mudança do caráter habitual dos estímulos que atuam sobre o sujeito.
Para Luria (ibidem, p. 22), há dois tipos de atenção: a atenção involuntária e a atenção arbitrária. A involuntária é muito comum nos seres humanos e está em suas bases neurofisiológicas, diz respeito à atração da atenção por um estímulo forte ou muito interessante. Nas primeiras etapas da vida da criança, essa atenção já ocorre, mas tem caráter instável e estreito devido ao seu volume. Por esse motivo, a criança tem maior capacidade de distribuir sua atenção em diversos estímulos e voltar-se para o antecedente com facilidade. A arbitrária, que é inerente ao ser humano, é a atenção que ele próprio pode direcionar de acordo com sua vontade, visto que possui controle sobre seu corpo e pode decidir e determinar seu comportamento. Luria (ibidem, p. 23) explica que "o comportamento do homem dispõe da possibilidade de criar quaisquer esquemas e subordinar o seu comportamento a essa esquematização livre". Os fenômenos desse tipo de atenção podem ser percebidos nas atividades intelectuais, em que o homem se propõe a realizar uma tarefa e esta determina o fluxo de suas associações.

Luria (ibidem, p. 24) também menciona que a atenção arbitrária possui caráter elástico, explicável e social, mediada pelos processos internos de linguagem. Ao se desenvolverem, esses processos vão se tornando complexos e automatizados e são observados, principalmente, quando somos capazes de manter a atenção numa atividade que nos interessa. 0 estudo sobre esse tipo de atenção representa maior interesse do que a involuntária e pesquisas sobre o seu volume são feitas por meio da análise do número de elementos que o sujeito pode perceber em um curto período de tempo. 0 estudo da estabilidade da atenção também é importante, visto que indica a solidez em alguma tarefa, por longo tempo. Para Luria (ibidem, p. 35),

a formação da atenção arbitrária abre caminho para a compreensão dos mecanismos interiores dessa complexíssima forma de organização de atividade consciente do homem, que desempenha papel decisivo em toda sua vida psíquica. 
Nos testes que envolvem a atenção arbitrária, aumentam-se as dificuldades através da discriminação dos fatores de abstração, pois a atenção arbitrária é produto de um desenvolvimento complexo.

Dessa forma, a atenção é um processo cognitivo muito importante para que tarefas complexas como a leitura ocorram, visto que, para que haja a compreensão do texto lido, o leitor deve ter sua atenção ativada durante todo esse processo. Sabendo das dificuldades que os estudantes têm quanto ao direcionamento do foco atencional, é importante buscar recursos que possam auxiliar no foco e na manutenção da atenção durante as tarefas.

\section{Metodologia}

Para este trabalho, o texto narrativo escolhido foi a fábula, justificado por ser curto e amplamente conhecido pelo público infantil. O texto selecionado foi "O Leão e o Ratinho" 4 e, para ele, foram criadas três atividades destinadas a estudantes do $6^{\circ}$ ano do Ensino Fundamental, que contemplassem os seguintes tópicos linguísticos: texto verbal e não verbal, sequências narrativas dominantes, progressão temática e ideia central por meio de palavras-chave. A partir desses aspectos, as atividades foram construídas em três diferentes softwares gratuitos, com o intuito de se verificar a aplicabilidade desses recursos para o desenvolvimento da atenção e da percepção da progressão temática do texto lido. Esses programas utilizados são ferramentas desenvolvidas para docentes e visam à diversificação da metodologia utilizada em sala de aula.

Tendo em vista essas informações, será, primeiramente, realizada a análise do texto selecionado, com base nos pressupostos teóricos apresentados anteriormente. Após, serão propostas as três atividades

${ }^{4}$ LA FOUNTAINE, Jean de. Disponível em: <http://pensador.uol.com.br/frase/ODEwNDAw/>. Acesso em: 26 mar. 2016. referentes à fábula selecionada e, por fim, será feita uma breve descrição dos softwares utilizados para a adaptação dessas atividades.

\subsection{Análise do Texto}

Sabendo que a progressão temática se caracteriza pela ordenação temporal, identificar as partes que compõem uma narrativa, conforme observamos, auxilia na construção de um texto narrativo coerente. A partir das proposições narrativas de Adam (2011, p. 205), apresentadas na seção 2, a fábula "O Leão e o Rato" está organizada da seguinte forma:

\begin{tabular}{|c|l|}
\hline Pn1 & $\begin{array}{l}\text { Certo dia, estava um Leão a dormir a sesta quando um ratinho começou a correr por cima } \\
\text { dele. } \\
\text { O Leão acordou, pôs-lhe a pata em cima, abriu a bocarra e preparou-se para engoli-lo. } \\
\text { - Perdoa-me! - gritou o ratinho - Perdoa-me desta vez e eu nunca o esquecerei. Quem sabe } \\
\text { se um dia não precisarás de mim? } \\
\text { O Leão ficou tão divertido com esta ideia que levantou a pata e o deixou partir. }\end{array}$ \\
\hline Pn2 & $\begin{array}{l}\text { Dias depois o Leão caiu numa armadilha. Como os caçadores o queriam oferecer vivo ao } \\
\text { Rei, amarraram-no a uma árvore e partiram à procura de um meio para o transportarem. }\end{array}$ \\
\hline Pn3 & Nisto, apareceu o ratinho. \\
\hline Pn4 & Vendo a triste situação em que o Leão se encontrava, roeu as cordas que o prendiam. \\
\hline $\operatorname{Pn} 5$ & E foi assim que um ratinho pequenino salvou o Rei dos Animais. \\
\hline $\operatorname{Pn} \Omega$ & Moral da história: Não devemos subestimar os outros. \\
\hline
\end{tabular}

O texto apresenta seis das sete proposições narrativas de Adam, sendo cinco delas de base e uma opcional. De forma resumida, a situação inicial (Pn1) refere-se ao momento em que o leão captura o ratinho, mas o liberta; o nó (Pn2), a quando o leão cai em uma armadilha; a reação (Pn3), ao aparecimento do ratinho; o desenlace (Pn4), a quando o ratinho rói as cordas que prendem o leão; a situação final (Pn5), à conclusão de que o ratinho acaba salvando o Rei dos Animais; e, por fim, $\operatorname{Pn} \Omega$, referente à moral da história, a qual se configura em um encerramento que não se insere diretamente na narrativa, mas que agrega uma avaliação final ao fato narrado. 
Dentro da estrutura narrativa dessa fábula, observa-se que a progressão temática não se desenvolve da mesma forma no texto inteiro. Os dois tipos dominantes são a progressão com tema constante e a progressão linear, como mostra o esquema ao lado (Fig. 2). Observa-se que "leão" é o tema recorrente na situação inicial (Pn1) da fábula analisada e se faz presente até o início do nó (Pn2), quando a ele é agregada a informação que indica o conflito. A partir desse momento, há uma mudança no foco temático do texto, que passa de "leão" para "caçadores". Essa alteração ocorre devido à omissão de um dos segmentos de uma progressão linear, caracterizando, dessa forma, uma sequência de progressão com salto temático. Mesmo com essa omissão, é possível depreender, a partir do contexto, o tema e rema: "A armadilha" (tema originado a partir de R6) "havia sido construída por caçadores do reino" (rema que daria origem a T7). Após esse salto temático, há o predomínio da progressão temática linear e os temas que aparecem referem-se às situações, aos fatos narrados na fábula. Um exemplo é o tema "E foi assim", que recupera a ideia apresentada no enunciado anterior - "roeu as cordas que o prendiam" - e a conecta a uma nova informação.

\subsection{Propostas de atividades}

A partir da análise do texto, serão descritas as atividades sugeridas para a contemplação dos tópicos linguísticos citados no início da seção 4.

\subsubsection{Atividade 1}

A primeira tarefa refere-se à organização da sequência narrativa da fábula "O leão e o rato" em sua versão em quadrinhos ${ }^{5}$. 0 estudante deve prestar atenção aos detalhes de cada figura (atenção arbitrária) e perceber

${ }^{5}$ História em quadrinhos retirada de: SÃO PAULO. Secretaria Municipal de Educação. Cadernos de apoio e aprendizagem: Língua Portuguesa - 4ํano/Secretaria Municipal de Educação. 2. ed. São Paulo: SME, 2014.
Figura 2 - Organização da progressão temática na fábula "O Leão e o Rato"

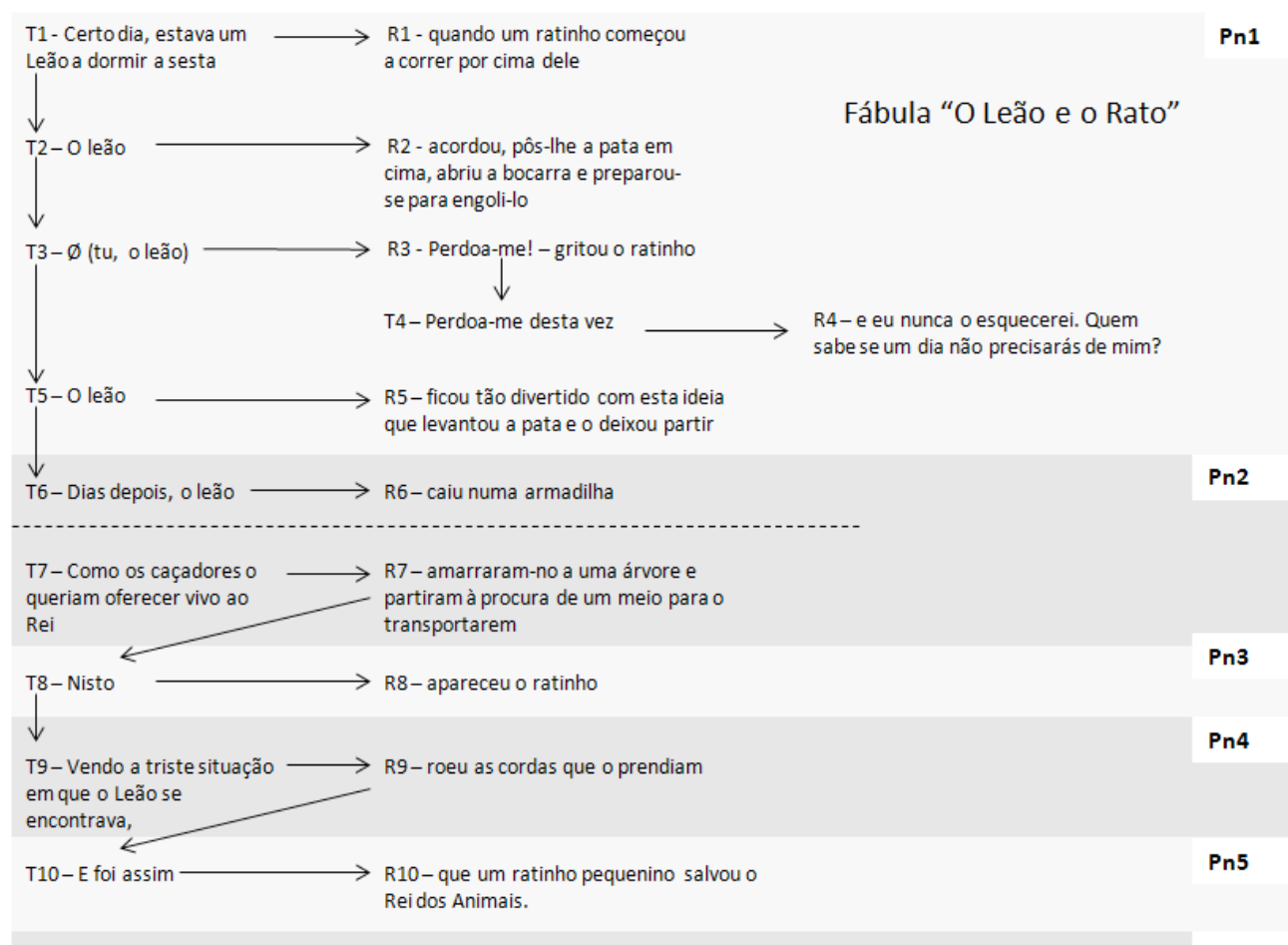

Moral da história: Não devemos subestimar os outros.

os elementos responsáveis por sua progressão temática, para que, dessa forma, consiga organizar adequadamente a história.

A história em quadrinhos é um texto que, de modo geral, agrada ao público infantil e infanto-juvenil e pode ser um estímulo forte para atrair a atenção (involuntária) dos estudantes. Embora a atividade proposta seja de ordenação, a desorganização dos estímulos a serem apresentados refere-se apenas à temporalidade dos fatos. Nas imagens, há elementos que, além de não serem aleatórios, repetem-se e dão ideia de estrutura. Um exemplo disso 
são as personagens envolvidas na narrativa, que se repetem nos quadrinhos e garantem a "unidade temática" do texto.

\subsubsection{Atividade 2}

A segunda atividade também diz respeito à sequência narrativa; porém, desta vez, do texto verbal. Essa proposta segue a mesma lógica da tarefa anterior: o texto é dividido em partes, conforme segmentação estabelecida na história em quadrinhos, e essas partes são misturadas aleatoriamente para que o estudante as ordene.

A atenção alocada nessa tarefa é a arbitrária, pois o estudante deve se focar nas ações principais e relacioná-las para estabelecer o todo. Como a primeira atividade envolve figuras, ela pode auxiliar o estudante a focar sua atenção nos elementos importantes e a reconhecê-los com mais facilidade.

Outra possibilidade de atividade é, ainda, relacionar cada parte do texto verbal com o quadrinho correspondente. Dessa forma, mesmo que a história em quadrinhos não seja mais um estímulo que apresente novidade, ela facilita a percepção de elementos importantes no texto e faz direcionar sua atenção a eles, além de tornar a atividade mais dinâmica e auxiliar na manutenção da atenção.

\subsubsection{Atividade 3}

A terceira atividade visa à identificação das informações importantes de cada uma das partes da fábula. Para tanto, o texto foi dividido em seis trechos e as ideias principais de cada trecho foram representadas por um conjunto de palavras-chave (todas substantivos). Dessa forma, o objetivo é que o estudante capte as ideias centrais das partes, perceba a sua progressão temática, a evolução dos fatos no decorrer do texto, e relacione-as ao grupo de palavras que as representam.
A atividade em si não traz estímulos muito diferentes, pois, na segunda tarefa, já era prevista a leitura da fábula "O Leão e o Rato". Novamente, o que pode motivar o interesse do aluno pela tarefa é a existência de um problema a ser resolvido. Para solucioná-lo, o estudante deve manter sua atenção ativa durante a leitura dos trechos, com o enfoque nas ideias que podem ser representadas pelos conjuntos de palavras-chave.

\subsection{Recursos Tecnológicos}

As atividades descritas foram construídas em três programas gratuitos, disponíveis na internet (Hot Potatoes, Ardora e JClic), os quais serão descritos brevemente nesta subseção.

\subsubsection{Hot Potatoes}

Hot Potatoes é o conjunto de seis programas de criação de páginas web, elaborado pela empresa de Pesquisa e Desenvolvimento da Universidade de Victoria, no Canadá. Nesse software, há cinco tipos de exercícios que podem ser criados: JQuiz, JClose, JCross, JMix e JMatch.

O JQuiz, é uma atividade que pode conter número ilimitado de perguntas, com modalidades diferentes. O JClose possibilita o preenchimento lacunar de texto; as lacunas permitem diversas respostas e o utilizador pode inserir pistas para os alunos. O JCross cria palavras cruzadas, e o JMix, exercício de frases desordenadas ou palavras embaralhadas. 0 JMatch viabiliza um exercício de ordenação de fatos, favorável para explorar a compreensão da progressão temática e a síntese textual do aluno, e possibilita também a criação de um exercício de associação, em que o aluno deve arrastar as palavras até as imagens, nomeando-as. Por fim, há o sexto aplicativo, chamado The Masher, que compila todos os exercícios do Hot Potatoes em um. O Hot Potatoes possibilita também a inserção de um timer, que pode ajudar na manutenção da atenção do aluno, fazendo com que não se disperse ao longo do exercício. 
A vantagem desse software é que os professores podem utilizá-lo na escola, e os exercícios criados possuem bastante variedade, propiciando recursos divertidos e não-repetitivos ao ensino. Esse programa, no entanto, não se configura como uma ferramenta para projetar provas e exames e não verifica a ortografia automaticamente.

\subsubsection{Ardora}

O programa Ardora v 7.3, criado por José Manuel Matanza, permite ao professor elaborar diversas atividades em formato $h t m l$, de forma compatível com diversos navegadores (Google Chrome, Mozilla, Internet Explorer, etc.). Nele, podem ser elaboradas atividades, como jogos de palavras (cruzadinhas, caça-palavras, forca), jogo da memória, de tabela, ordenação de frases e de parágrafos, completar textos, entre outras. Após a inserção das informações no programa, que necessita ter o plug-in do Java instalado no computador, automaticamente abrirá uma página web com a atividade salva. Portanto, tratando-se da aplicação das atividades em ambiente escolar, não é necessário ter o software instalado em diversos computadores.

O Ardora, além de ser oferecido no idioma português brasileiro, é de fácil instalação e manuseio, não necessitando de conhecimentos de programação ou de design. Nele, é possível escolher fonte, cor e plano de fundo, bem como a opção de cronometrar o tempo de execução da atividade e de colocar mensagens de acerto ou erro para o aluno. Seus recursos, no entanto, são mais apropriados para atividades simples, que não envolvam o uso de muitas animações ou sons.

\subsubsection{JClic}

O JClic, criado por Francesc Busquest, é uma versão atualizado do programa Clic e possibilita a criação, a realização e a avaliação de atividades educativas em diferentes disciplinas curriculares. Seu sistema foi desenvolvido na plataforma Java e disponibiliza recursos para atividades que podem ser desde quebra-cabeças, associações, palavras cruzadas, até estudo de texto, podendo ser agrupadas em projetos específicos, com sequências que indicam a ordem em que devem ser executadas pelos estudantes (cf. PARANÁ, 2010, p. 10).

Esse software também não exige conhecimentos de programação; no entanto, faz-se necessário, assim como no programa Ardora, a instalação de uma versão atualizada de Java. Feito isso, o programa JClic poderá ser instalado. Nele, são disponibilizados três aplicativos: JClic Player, JClic Author e JClic Reports. O primeiro é o principal; nele é possível ver e executar as tarefas. O segundo permite a criação, modificação e experimentação dos projetos, bem como a publicação das atividades em uma página da web ou também a criação de arquivos de instalação de projeto JClic. O terceiro, por sua vez, é a ferramenta que possibilita o gerenciamento de uma base de dados, em que são armazenados os resultados obtidos pelos alunos na realização das tarefas.

\section{Resultados: análise da funcionalidade dos programas}

As três atividades propostas neste trabalho foram adaptadas nos softwares Hot Potatoes, Ardora e JClic. Os resultados dessas produções serão descritos e analisados a seguir.

\subsection{Atividade 1}

\subsubsection{Hot Potatoes}

A atividade envolvendo a ordenação de quadrinhos para formar a sequência narrativa da fábula "O Leão e o Rato", como apresentado na seção 4.2.1, requer do estudante a atenção aos detalhes de cada parte da 
história, representada em figuras, e sua percepção acerca do encadeamento das proposições narrativas que a compõem. Com a utilização do programa Hot Potatoes, buscaram-se recursos que pudessem auxiliar no foco atencional do estudante e que o motivassem na execução da tarefa.

Assim, essa atividade foi elaborada no JMatch, que possibilitou a criação de duas colunas para associação. As figuras foram colocadas ao lado direito, e os números, ao lado esquerdo (conforme Fig. 3).

Figura 3 - Programa Hot Potatoes - atividade 1

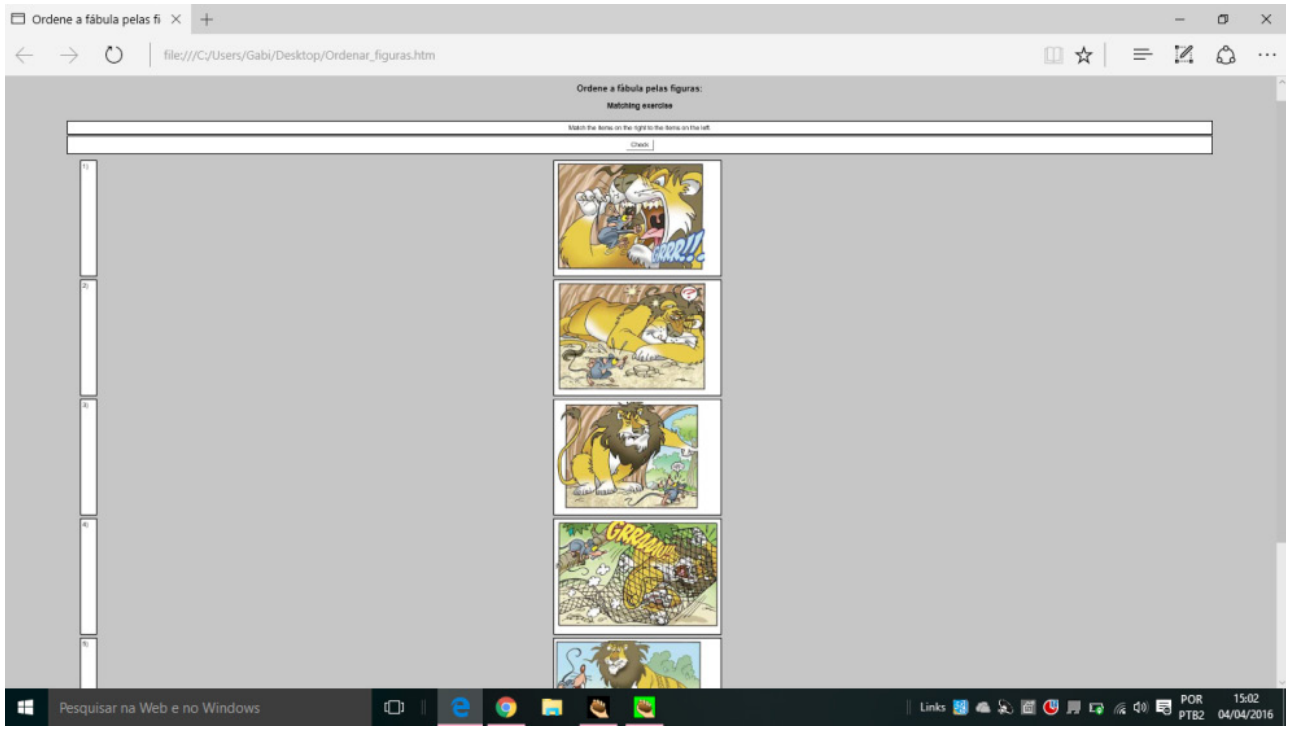

O estudante, ao executar a tarefa, deve relacionar os números, que representam a ordem em que os fatos ocorrem, às figuras e, ao final da ordenação, deve clicar em check para verificar sua pontuação, apurada em porcentagem. Nesse formato, a atividade torna-se lúdica, podendo despertar o interesse do estudante e motivá-lo a engajar-se nela. A pontuação, além de poder ser um fator motivacional, pode auxiliar no foco atencional do usuário durante a tarefa.

\subsubsection{Ardora}

No software Ardora V. 7.3, foi acessível adaptar a primeira atividade, pois há a opção de inserir as imagens da história na sequência correta e solicitar ao programa que as ordene aleatoriamente. A tarefa (Fig. 4) pode ser cronometrada, e há a possibilidade de acrescentar som e frase motivadora para as respostas corretas. Esses recursos podem auxiliar no foco e na manutenção da atenção do aluno, levando à sustentação de seu interesse durante a atividade.

Figura 4 - Programa Ardora V.7.3 - atividade 1

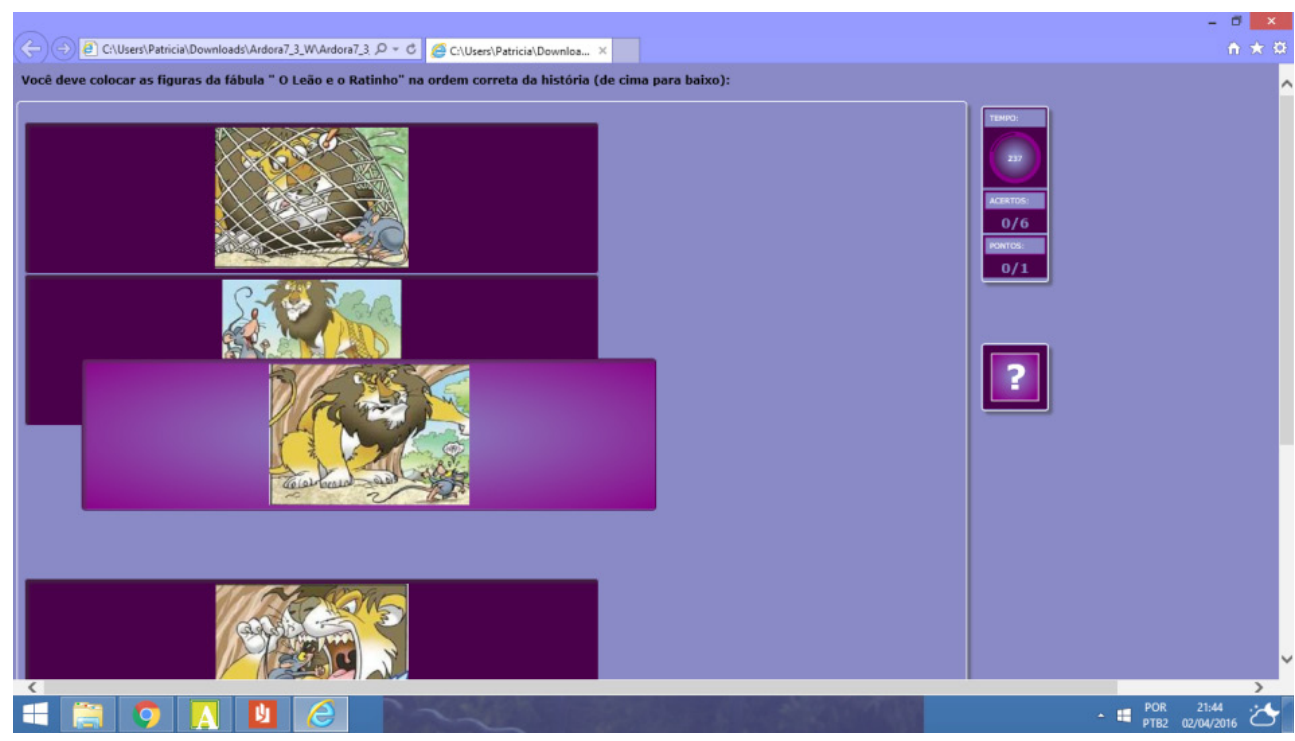


O único problema encontrado para adaptar a tarefa a esse programa foi a impossibilidade de destinar espaços específicos para a alocação das partes da fábula, o que pode tornar um pouco confusa a forma de se determinar a ordem correta no exercício. O ideal seria numerar os espaços como forma de guiar o aluno. Por esse motivo, colocamos, no enunciado, a orientação "de cima para baixo".

Como pôde ser observado, esse software apresenta recursos muito parecidos com os disponíveis no Hot Potatoes, os quais podem ser utilizados para tentar sustentar o foco atencional do estudante durante a tarefa. No entanto, o layout apresentado pelo programa Ardora aparenta ser mais moderno e, provavelmente, isso possa ser um fator que atraia mais a atenção (involuntária) do aluno para realizá-la.

\subsubsection{JClic}

No JClic, a atividade foi classificada como quebra-cabeça, o que viabilizou a segmentação da história em "blocos" (com encaixes retangulares) e criou, automaticamente, um espaço para as peças serem depositadas em sua ordem correta (Fig. 5).

Quando o usuário aloca a peça corretamente, ela se fixa em seu dispositivo. No entanto, se houver um erro, a peça retorna à sua posição de origem. Esse programa possibilita inserir sinais sonoros para indicar erro e acerto na execução da tarefa, bem como mensagens de motivação para o estudante. Há também outros recursos que podem estimular a atenção do aluno, como o "placar" com o número de acertos e de tentativas e o campo indicador de tempo. No que se refere a esse último, é possível configurá-lo para informar o tempo despendido na realização da atividade ou para deixálo em forma de cronômetro, o que desafia ainda mais a sustentação do foco atencional do estudante, pois deverá resolver o problema proposto antes do tempo findar. Dessa forma, esses estímulos externos, possibilitados por meio dessa ferramenta tecnológica, podem auxiliar no direcionamento da atenção e tornarem-se fatores motivacionais para a sua sustentação durante a execução da tarefa.

Figura 5 - Programa JClic - atividade 1

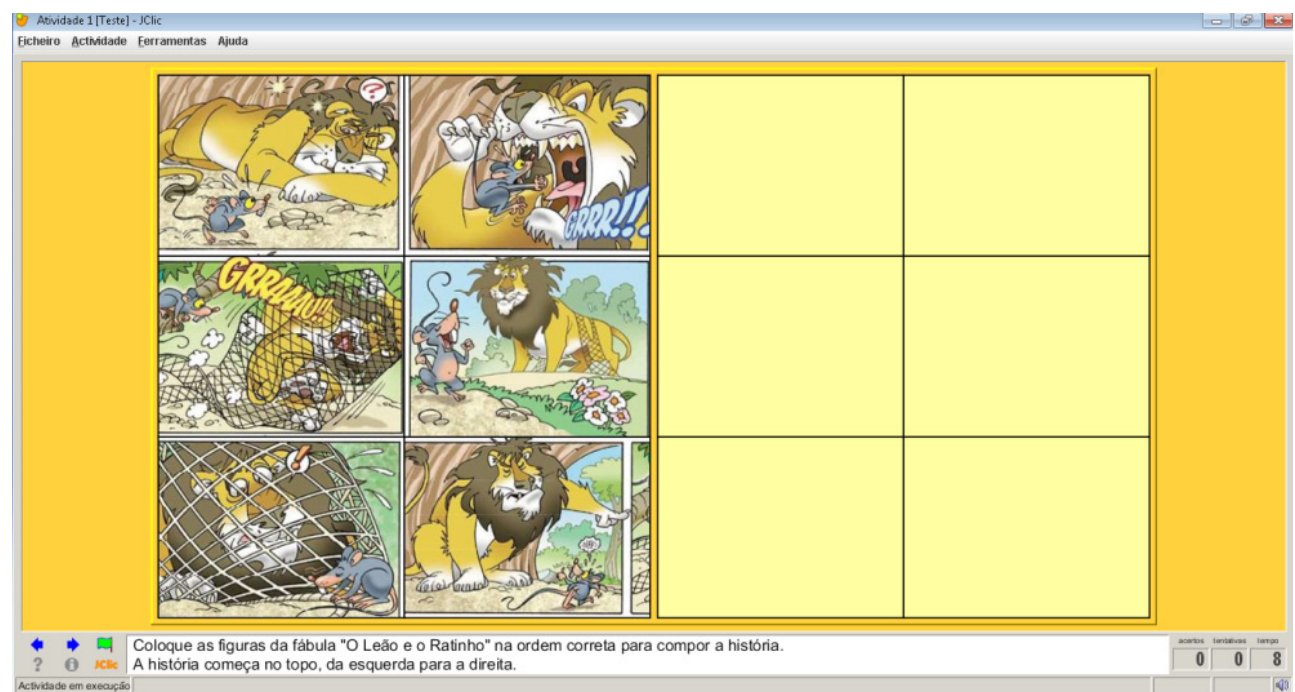

Um dos aspectos negativos desse programa foi a impossibilidade de alterar a configuração do espaço para a alocação das partes da fábula (a não ser a cor de fundo). Seria interessante poder numerar cada um dos quadros para guiar o usuário na realização da organização da narrativa e da leitura do texto (de cima para baixo, da esquerda para a direita). Nesse sentido, apesar de ter problema parecido, a configuração do layout da atividade pelo programa Ardora possibilitaria menos equívocos para sua execução, tendo em vista que, obrigatoriamente, o usuário deve ordenar as figuras na direção vertical. 


\subsection{Atividade 2}

\subsubsection{Hot Potatoes}

A segunda atividade refere-se à ordenação dos trechos do texto verbal e visa à percepção de elementos importantes que levem ao estabelecimento da sequência narrativa, da progressão temática, tornando o texto coerente. No software Hot Potatoes, foi difícil a construção dessa tarefa, uma vez que não havia um recurso específico para suprir a nossa proposta. Em um primeiro momento, foi feita a tentativa de realizá-la no JMix, porém a atividade não atingiu os objetivos (Fig. 6). As partes do texto ficaram sobrepostas e, ao finalizar a atividade, o programa sentenciava a ordenação, mesmo que corretamente estabelecida, como errada.

Figura 6 - Programa Hot Potatoes - atividade 2 - Texto verbal

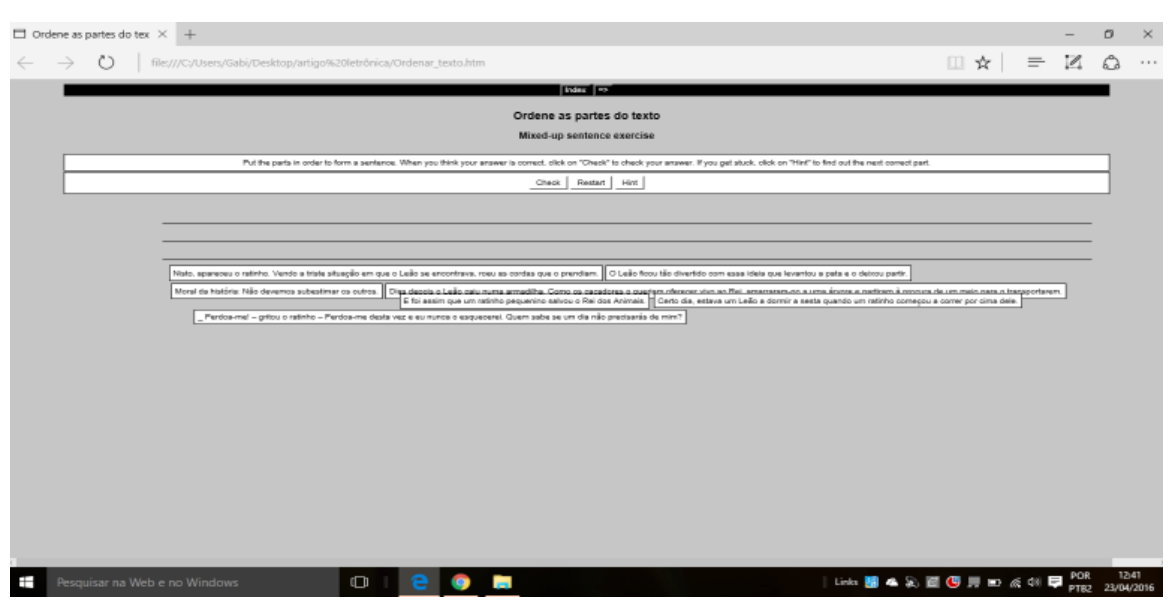

Então, a melhor proposta foi a de relacionar as imagens do texto com as partes do texto verbal. Esta atividade foi criada com o JMatch. Após salvar o arquivo, foi possível inserir as imagens da história. Na coluna da esquerda, foram alocadas as figuras na ordem que são apresentadas na fábula em quadrinhos e, na da direita, foram colocados os trechos do texto verbal (na ordem correta, para que o programa tenha a referência da ordem - como um gabarito). Ao exportar o documento para a página web, o programa cria a atividade (como pode ser visto na Figura 7), com os trechos do texto verbal desordenados, para que o aprendiz realize a ordenação, relacionando-o com as imagens da fábula.

Figura 7 - Programa Hot Potatoes - atividade 2 - Textos verbal e não-verbal.

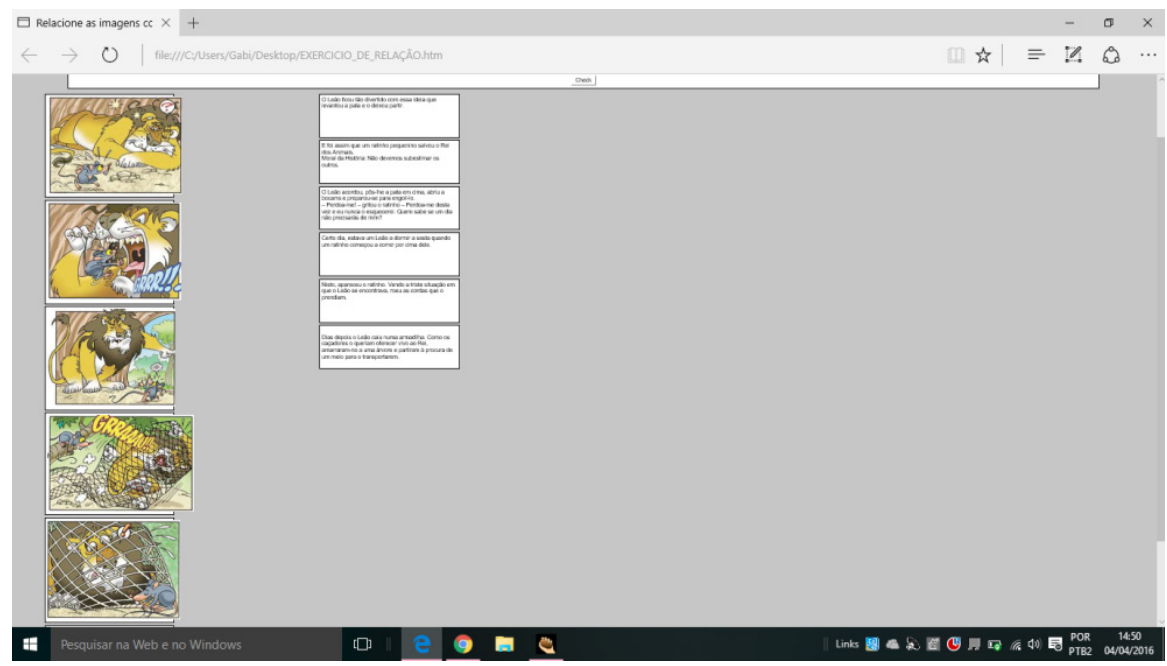

Na construção das atividades, percebeu-se que os recursos disponíveis nesse programa são um pouco precários. Primeiramente, porque não foi possível criar a tarefa de ordenação do texto verbal de forma satisfatória; segundo, porque o layout da atividade de associação entre texto verbal e não-verbal desfavorece a execução da tarefa, já que as figuras não se adaptam ao tamanho das caixas de texto, o que prejudica o aspecto visual e simétrico 
da atividade. Sendo assim, embora a atividade possa ser cronometrada, o que poderia auxiliar na sustentação da atenção ao longo da tarefa, o aspecto visual pode prejudicar a atenção involuntária aos estímulos apresentados e, devido à desproporcionalidade entre os textos, dar mais destaque ao texto não-verbal.

\subsubsection{Ardora}

No programa Ardora V. 7.3 foi acessível adaptar essa atividade. Tendo em vista os objetivos da atividade 2, esse software disponibiliza as opções tanto de organizar as partes do texto como de relacioná-las com suas respectivas imagens, esta última apresentada na Figura 8.

Figura 8 - Programa Ardora - atividade 2 - Textos verbal e não-verbal

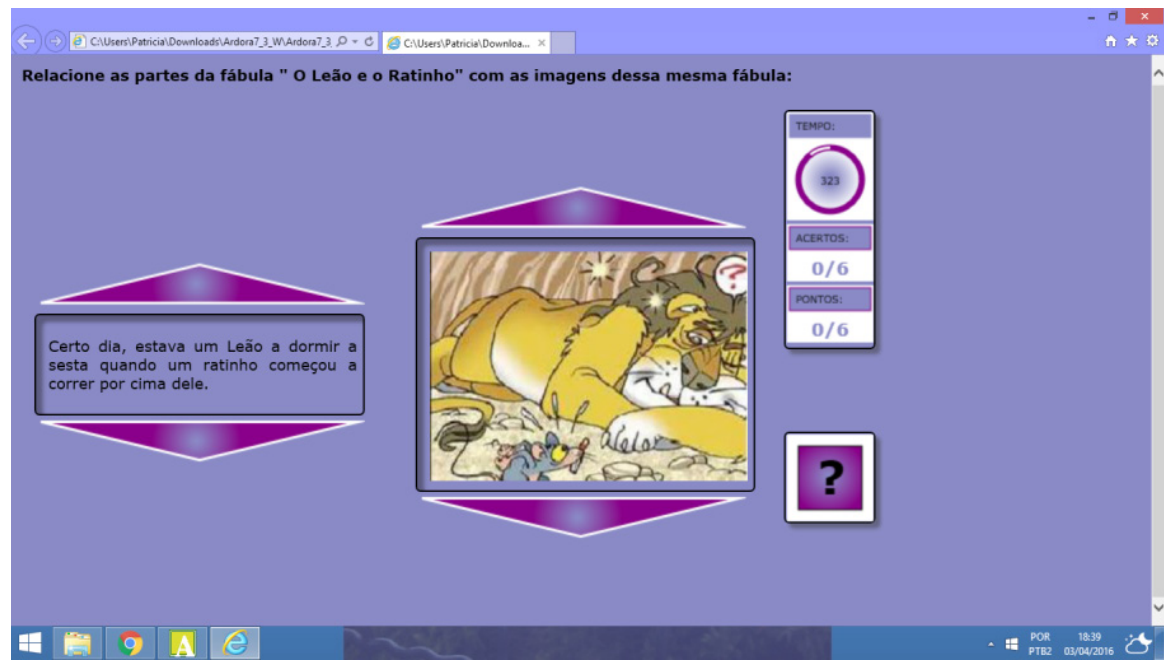

Como já mencionado anteriormente, é possível cronometrar a atividade e utilizar sons e frases motivacionais a cada acerto e tentativa, além da informação do número de acertos e da pontuação obtida. Esses recursos podem ajudar o aluno a focar sua atenção e sustentá-la ao longo da tarefa, visto que o estudante precisa resolver um problema em um determinado tempo e obter a maior pontuação possível. Sendo assim, a única forma de cumprir com esses quesitos é a ativação da atenção durante todo o processo. Nesse sentido, a ferramenta tecnológica possibilita uma atividade mais interativa e atrativa (influenciada também pelo layout apresentado), colaborando para a atenção involuntária do estudante e motivando-o a engajar-se nela.

\subsubsection{JClic}

No JClic, para a criação da atividade referente à ordenação do texto verbal, utilizou-se o recurso de Texto: ordenar elementos. Com a inserção do texto, foram marcados os limites de cada trecho para que sejam desordenados. Ao realizar a tarefa, o usuário deve clicar na parte desejada e arrastá-la para a posição que julgue ser a correta dentro do texto. 0 trecho ficará destacado e uma linha apontará o direcionamento do parágrafo na tela, conforme a Figura 9. Além disso, é possível verificar se as respostas estão corretas ao longo de sua execução.

Em relação a essa proposta, há alguns pontos negativos nos recursos disponibilizados por esse programa. Um exemplo é a impossibilidade de alterar o tamanho da fonte depois de criar os limites dos trechos; a letra fica muito reduzida, o que pode dificultar a leitura e desmotivar o estudante para a tarefa. Além disso, não há uma delimitação aparente dos trechos que devem ser ordenados e isso pode fazer com que o usuário tenha problemas para selecionar e deslocar as partes do texto ao local desejado.

No entanto, obteve-se um resultado bastante positivo quanto à atividade de relacionar o texto verbal ao não-verbal. Classificando a tarefa como associação simples, possibilitou-se a criação de duas áreas na tela, uma para as imagens da história em quadrinhos e outra para as partes do texto (Fig. 10). 
Figura 9 - Programa JClic - atividade 2 - Texto verbal

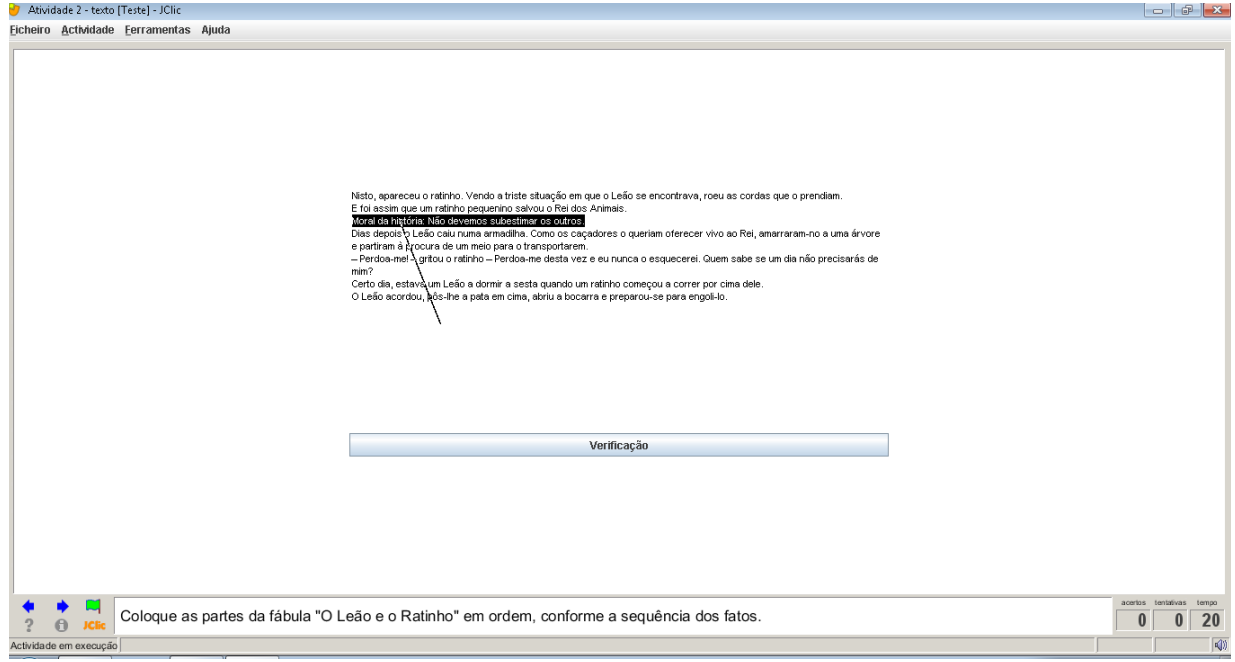

Figura 10 -Programa JClic - atividade 2 - Textos verbal e não-verbal

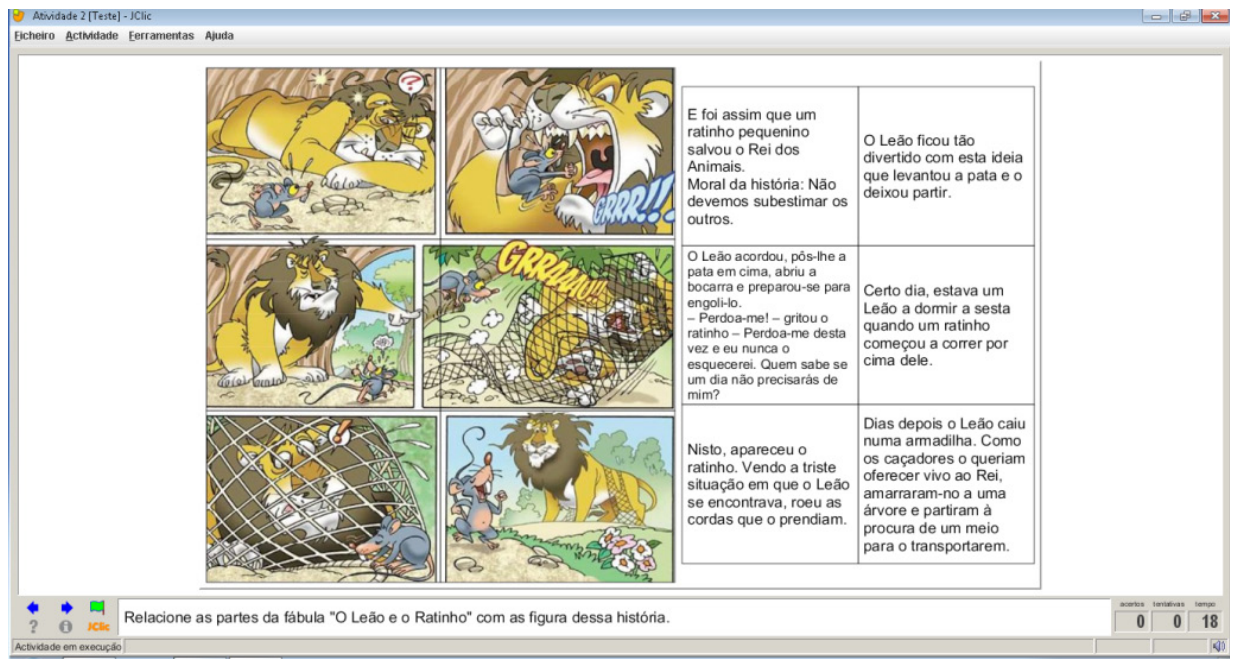

O estudante deve clicar na figura e arrastar a seta até o trecho correspondente. Se a associação estiver correta, a imagem e o trecho somem. Por esse motivo, seria interessante também vincular uma segunda etapa a essa atividade, em que a leitura do texto é solicitada. Uma sugestão (Fig. 11) é apresentar novamente a história em quadrinhos (na ordem correta) e pedir que o usuário, ao clicar em cada quadro, leia o trecho que aparece.

Figura 11 - Programa JClic - atividade 2 - Leitura da fábula

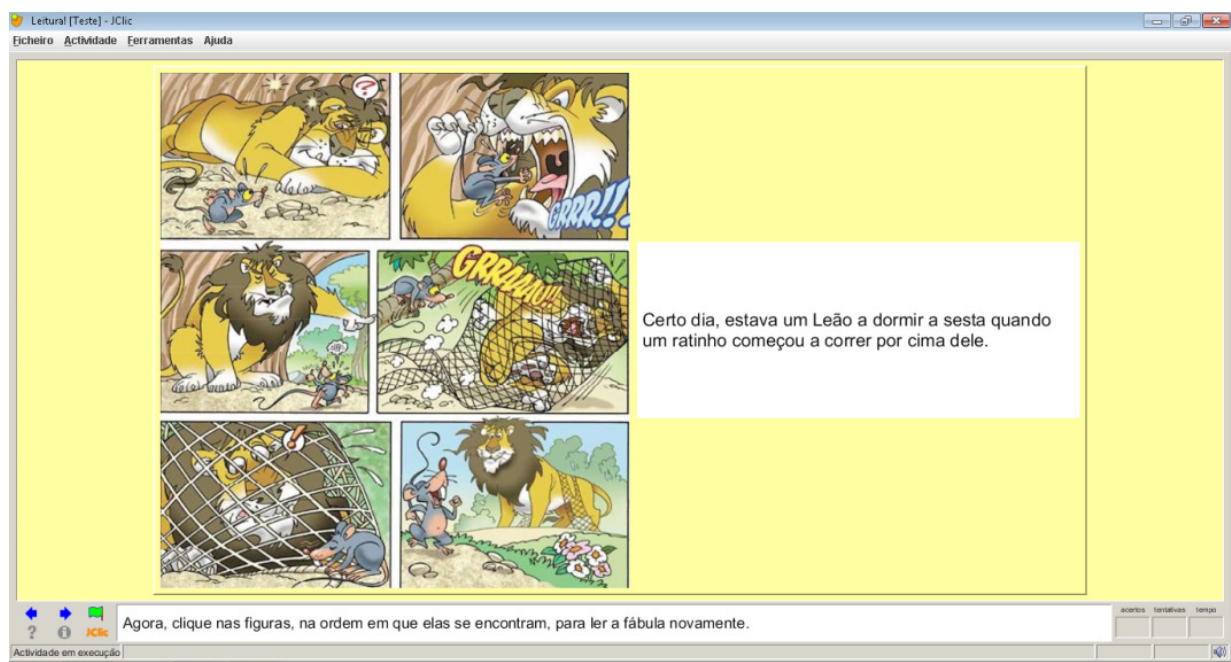

A atenção do estudante para a atividade de relacionar imagem a texto pode ser motivada pelo interesse em resolver um problema (fazer com que todas as peças desaparecessem da tela) e, portanto, direcionada aos detalhes da imagem e aos fatos narrados. Além disso, pode ser motivada pela presença de estímulos que provocam ocorrências de alerta e de expectativa, como as informações de tempo, de número de acertos e de tentativas. $\mathrm{Na}$ segunda etapa dessa tarefa, no entanto, não há estímulos novos e nem uma 
desafio a ser cumprido; sendo assim, o professor poderia propor questões de compreensão desse texto a serem realizadas ao final da leitura.

\subsection{Atividade 3}

\subsubsection{Hot Potatoes}

A tarefa 3 corresponde à identificação das informações importantes, representadas por conjuntos de palavras-chave, de cada uma das partes do texto. Para tanto, utilizou-se, no Hot Potatoes, o aplicativo JMatch, o qual possibilitou a formação de duas colunas, em que foram inseridos trechos do texto (respeitando a ordem numérica) e blocos com suas respectivas palavras-chave. Ao exportar para a página, as palavras-chave se embaralham, criando, assim, o exercício para realizar associações (Fig. 12).

Figura 12 - Programa Hot Potatoes - atividade 3

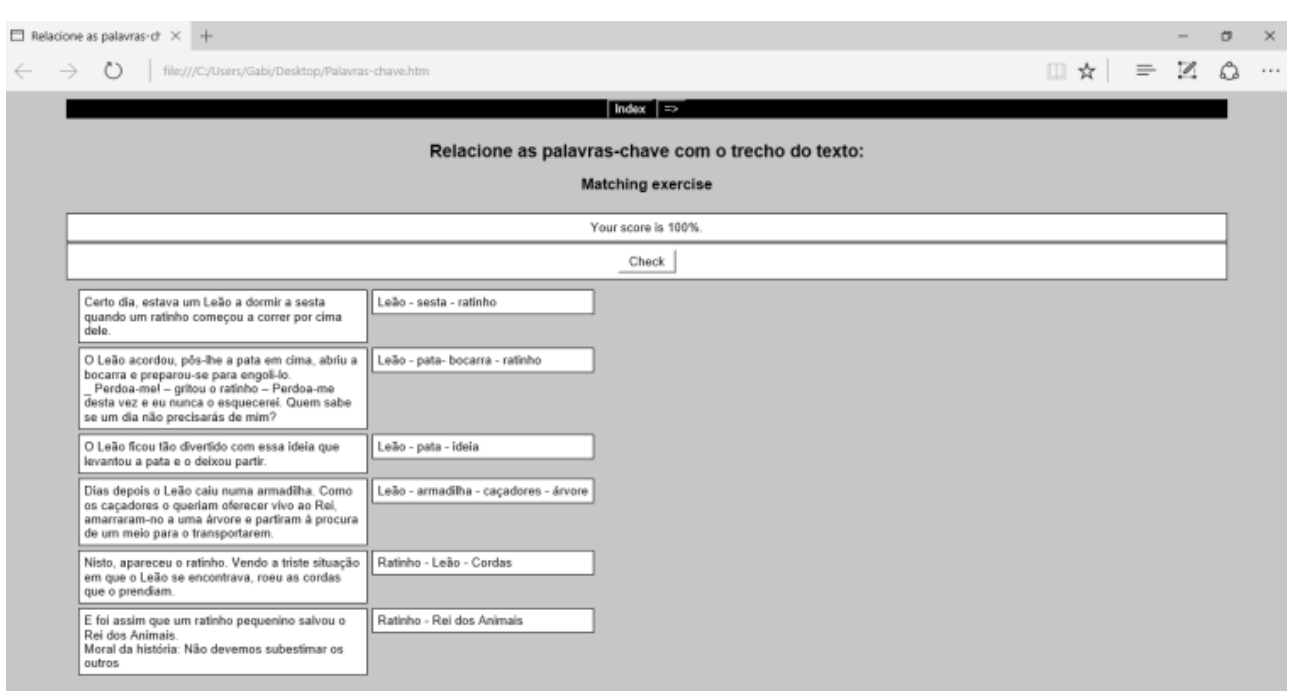

Nessa tarefa, além de trabalhar com a captação das ideias centrais que compõem o texto, a fim de perceber sua progressão temática, a atenção do estudante pode ser atraída pelo interesse em solucionar o problema com o máximo de aproveitamento possível (escore de 100\%). Além disso, o reflexo orientado a essa tarefa pode levar à seletividade da atenção às palavraschave durante a leitura dos trechos.

\subsubsection{Ardora}

A atividade 3 também pôde ser satisfatoriamente adaptada no programa Ardora. Assim como no Hot Potatoes, na coluna da esquerda, ficam as partes da fábula e, da direita, os conjuntos de palavras-chave (Fig. 13).

Figura 13 - Programa Ardora - atividade 3

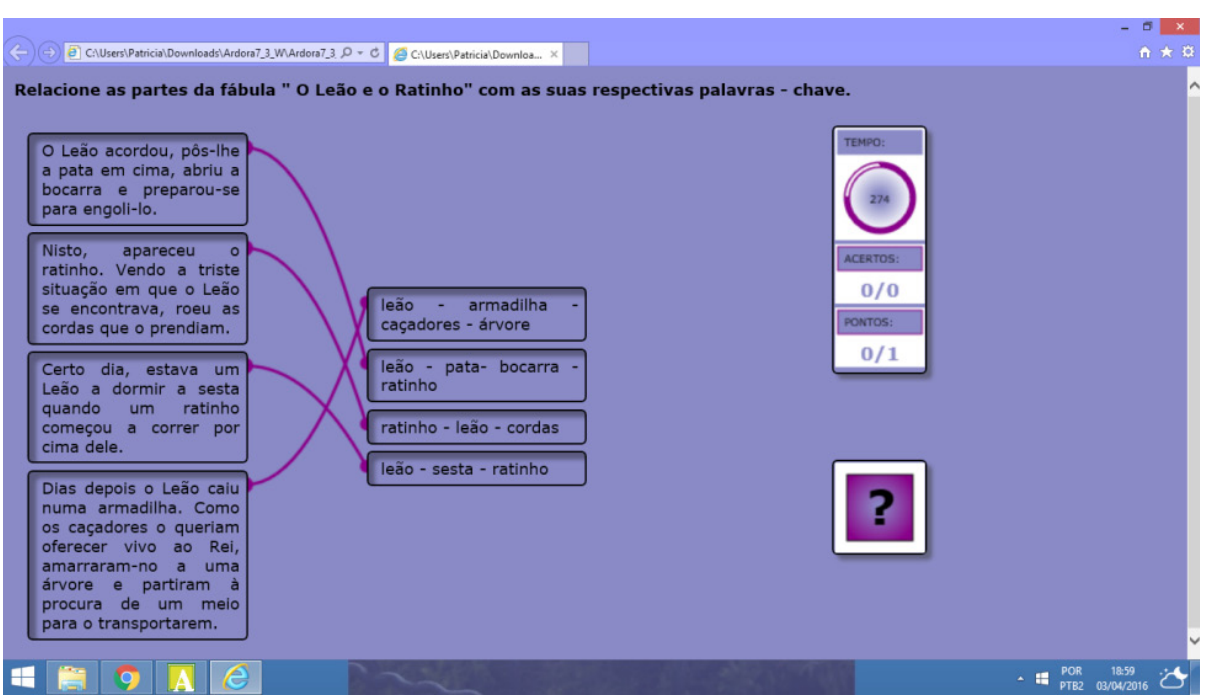

Assim como nas outras atividades, esse software promove grande interatividade, contendo sons a cada tentativa de relacionar os elementos 
das duas colunas e frases motivacionais a cada acerto, bem como a opção de cronometrar a execução da atividade. Esses recursos, como mencionado anteriormente, podem auxiliar na sustentação da atenção e no foco em informações importantes que servirão para solucionar a tarefa. Além disso, é importante destacar que a atenção involuntária, a partir dos estímulos externos, é essencial para atrair a atenção do estudante e motivá-lo a ler o texto e realizar o que se pede. Nesse sentido, a apresentação visual da tarefa é fundamental e o programa Ardora consegue dar conta desse aspecto, mais do que o Hot Potatoes.

\subsubsection{JClic}

No JClic, o layout da atividade 3 ficou semelhante ao obtido nos outros programas. Assim, foram criadas duas colunas com as informações a serem relacionadas (Fig. 14).

Figura 14 - Programa JClic - atividade 3

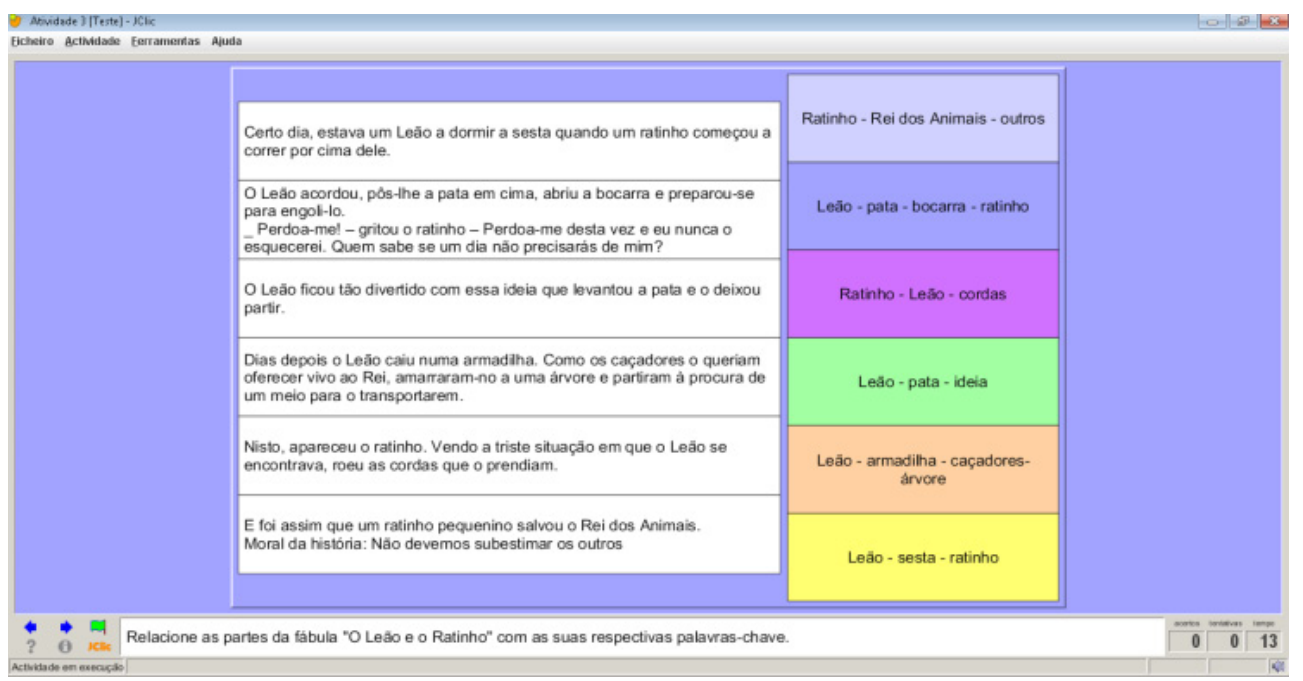

O estudante, ao clicar no trecho selecionado, projeta uma linha que deverá ser arrastada até o conjunto de palavras correspondente. Caso a associação estabelecida esteja correta, além de haver um sinal sonoro, o trecho e o bloco de palavras-chave desaparecem.

Os recursos para tentar motivar o interesse do aluno, bem como focar e sustentar sua atenção durante a execução da tarefa, também se assemelham aos dos demais programas. 0 que provavelmente possa ser algo não muito favorável à utilização do JClick para essa proposta é a exclusão das partes que já foram associadas corretamente, pois o estudante acaba perdendo a possibilidade de ter uma visão da atividade em sua totalidade e de, até mesmo, reler o texto. Por esse motivo, tanto o Hot Potatoes quanto o Ardora poderiam ser mais adequados para essa proposta de atividade.

\section{Conclusão}

Tendo esse artigo a finalidade de realizar uma análise da funcionalidade de ferramentas tecnológicas na construção de atividades que visam o trabalho com sequências narrativas textuais e no desenvolvimento da atenção, realizou-se uma revisão teórica sobre leitura e compreensão, progressão temática e atenção. Como visto, o leitor precisa ter competência sintática, semântica e textual, além de uma competência específica da realidade histórico-social refletida pelo texto, para compreendê-lo por completo. A coesão e a coerência são conceitos intimamente relacionados, responsáveis pela textualidade.

A progressão temática, por sua vez, é um dos aspectos que torna o texto coerente e permite que ele seja fluido ao restringir a repetição excessiva do mesmo tópico durante toda produção textual e ao prever um equilíbrio entre o tema e a informação nova para que não haja quebra na continuidade temática. Logo, a progressão temática é de suma importância 
ao texto. 0 indivíduo percebe melhor os estímulos que estiverem ordenados do que os desordenados (LURIA, 1979, p. 38) e, por esse motivo, essa organização (progressão temática) auxilia na manutenção da atenção e, consequentemente, na sustentação da leitura de um texto.

A função da atenção é selecionar a atividade consciente, manifestandose igualmente na percepção, nos processos motores e no pensamento. Se não houvesse a seleção, não teríamos como organizar todo o pensamento e a informação, nem solucionar problemas. Assim sendo, todo o conhecimento sobre esses aspectos são importantes antes de elaborar atividades que tenham como objetivo desenvolver a leitura.

Com o enfoque na progressão temática, foram elaboradas três atividadesbase: 1) ordenação da sequência narrativa da fábula em quadrinhos; 2) ordenação da sequência narrativa do texto verbal e a associação entre os textos verbal e não-verbal; e 3) relação entre as ideias principais e as palavras-chave que as representam. Essas tarefas requerem do estudante atenção ativa para que sejam obtidas as ideias principais de cada parte do texto e para que sejam percebidos os elementos responsáveis pela progressão temática. Os programas utilizados para sua construção foram Hot Potatoes, Ardora e JClic, os quais apresentaram resultados diferentes.

Observou-se que o software Ardora foi o que mostrou melhor apresentação visual das atividades, o que pode auxiliar na atenção involuntária do estudante. Por possuir estímulos fortes, interessantes, a sua atenção pode ser atraída mais facilmente, motivando-o a realizar a tarefa. 0 Hot Potatoes, por outro lado, foi o que teve a pior apresentação visual, principalmente no que se refere à proporção e à distribuição dos elementos da atividade na tela.

Os três programas apresentaram alguns recursos semelhantes, como a possibilidade de inserção de sinais sonoros diferentes para erros e acertos, mensagens de motivação, campos com indicadores do número de pontuação e de tentativas, assim como de tempo (decorrido ou na função cronômetro).
Essas funcionalidades podem auxiliar no foco e na manutenção da atenção do usuário durante a tarefa, como um desafio que precisa ser resolvido, dentro de um período estipulado ou no menor tempo, com a maior pontuação e o menor número de tentativas possível. Em geral, desafios motivam as crianças e essa seria uma forma de fazer com que a sua atenção ficasse ativa e se sustentasse ao longo da tarefa.

Com relação à transposição das diferentes atividades para os programas citados, observou-se que não há recursos específicos satisfatórios para trabalhar com a ordenação das partes do texto. No entanto, com o recurso de associação, foi possível, nos três softwares, criar a tarefa de relação entre as partes do texto verbal e do texto não-verbal. Com essa mesma funcionalidade, foi possível a elaboração da terceira atividade, referente à associação entre trechos e palavras-chave.

Dentre as três tarefas, a que teve maior diferença de resultado foi a primeira, devido aos recursos disponíveis nos programas. No Hot Potatoes, foi necessário utilizar a função de associação para ser possível estabelecer a ordenação das figuras da história. No JClic, a função utilizada foi a de quebra-cabeça, o que possibilitou usar a imagem original para sua construção (nos outros programas foi necessário separar cada quadrinho da história), segmentar automaticamente as partes da história e criar também, automaticamente, o espaço em que a sequência narrativa deveria ser organizada. No Ardora, utilizou-se um recurso próprio para a ordenação dos quadrinhos; além disso, apesar de não haver indicação da direção do ordenamento das figuras, ainda assim possibilitaria menos equívocos para sua realização do que no programa JClic, que poderia ser na direção horizontal ou vertical.

Por fim, percebe-se que os três programas apresentam funcionalidades que podem colaborar com o trabalho do professor no que se refere à percepção da progressão temática e ao desenvolvimento da atenção do 
estudante. O software que se mostrou mais acessível para a elaboração das atividades propostas foi o Ardora; porém, os demais, apesar dos aspectos negativos que foram citados neste trabalho, também podem ser utilizados e adaptados conforme a necessidade do docente. 0 acesso e a utilização de cada um desses programas dependem do domínio do professor em relação às ferramentas tecnológicas, da disponibilidade de criar atividades deste cunho e do objetivo de suas aulas.

\section{Referências}

ADAM, Jean Michel. A Línguística Textual. São Paulo: Cortez, 2011.

BEAUGRANDE, Robert A.; DRESSLER, Wolfgang U. Introduction to text linguistics. New York: Logman, 1983.

CHAROLLES, Michel. Introduction aux problèmes de la cohérence des textes. Paris: Langue Française, 1978.

COLOMER, Teresa; CAMPS, Anna. Ensinar a ler, ensinar a compreender. Porto Alegre: Artes Médicas Sul, 2002.

COMMODARI, Elena; GUARNERA, Maria. Attention and reading skills. In: Perceptual and Motor Skills, v. 100, p. 375-386, 2005. http://dx.doi.org/10.2466/pms.100.2.375-386

FERREIRA, Sandra P. A.; DIAS, Maria G. B. B. A leitura, a produção de sentidos e o processo inferencial. In: Psicologia em Estudo, Maringá, v. 9, n. 3, p. 439-448, set./dez. 2004

FONSECA, Luísa. Compreensão leitora e atenção seletiva: um estudo com alunos do ensino médio. Dissertação de mestrado, 2013.

GIASSON, Jocelyne. A compreensão na leitura. 2. ed. Porto, Portugal: ASA Editores II, 2000.

GOODMAN, Kenneth S. Um jogo psicolinguístico de adivinhação. In: SINGER, Harry; RUDDELL, Robert B. Theoretical models and processes of reading. 2. ed. Newark: Internacional Reading Association, 1976.

O processo de leitura: considerações a respeito das línguas e do desenvolvimento. In: FERREIRO, Emília; PALÁCIO, Margarita Gomez. Os processos de leitura e escrita, novas perspectivas. 3. ed. Porto Alegre: Artes Médicas Sul, 1990.
Unidade na leitura - um modelo psicolingüístico transacional. In: Letras de Hoje, Porto Alegre, v. 26, n. 4, p. 9-43, dez. 1991.

HALLIDAY, M. A. K.; HASAN, Ruqaiya. Cohesion in English. London: Longman, 1976.

KATO, Mary Aizawa. O aprendizado da leitura. 6. ed. São Paulo: Martins Fontes, 2007.

KLEIMAN, Ângela. Texto e leitor: aspectos cognitivos da leitura. 2. ed. Campinas, SP: Pontes, 1992.

KOCH, Ingedore. G. V. Desvendando os segredos do texto. São Paulo: Cortez, 2002.

Introdução à Linguística Textual: trajetória e grandes temas. São Paulo: Martins Fontes, 2004.

_. A coesão textual. São Paulo: Contexto, 2013.

LEFFA, Vilson J. Aspectos da leitura. Porto Alegre: D. C. Luzzatto, 1996.

LURIA, Alexander Romanovich. Curso de Psicologia Geral. Civilização Brasileira. Rio de Janeiro: 1979. Vol. 3

MOREIRA, Terezinha Maria. A progressão temática na redação escolar. Dissertação (Mestrado) - Universidade de Campinas, Campinas, 1991.

PARANÁ. Secretaria de Estado da Educação. Manual para uso do JClicl. Cutitiba: Secretaria de Estado da Educação, 2010.

PEREIRA, Vera Wannamacher. Arrisque-se... faça seu jogo. Letras de Hoje, Porto Alegre, v. 37, n. 2, p. 47-63, 2002.

SIMON, Maria Lúcia M. A construção do texto: coesão e coerência textuais. In: Revista Philologus, v. 40, p. 23-31, 2008

SMITH, Frank. Leitura significativa. 3. ed. Porto Alegre: Artes Médicas Sul, 1999.

Compreendendo a leitura: uma análise psicolinguística da leitura e do aprender a ler. 4. ed. Porto Alegre: Artes Médicas Sul, 2003.

Introdução à linguística textual. São Paulo: Martins Fontes, 2004.

Recebido em 25/04/2016

Aceito em 07/07/2016. 